\title{
HIGH RESOLUTION BIOSTRATIGRAPHY AND PALEOECOLOGY OF THE EARLY PLIOCENE SUCCESSION OF PISSOURI BASIN (CYPRUS ISLAND)
}

\author{
Triantaphyllou M. V. ${ }^{1}$, Antonarakou, A. ${ }^{1}$, Drinia, H. ${ }^{1}$, Dimiza M. D. ${ }^{1}$, \\ Kontakiotis, G. ${ }^{1}$, Tsolakis, E. ${ }^{2}$ and Theodorou, G. ${ }^{1}$ \\ ${ }^{1}$ Department of Historical Geology and Palaeontology, Faculty of Geology and Geoenvironment, \\ University of Athens, Panepistimiopolis 15784, Athens, Greece,mtriant@geol.uoa.gr \\ ${ }^{2}$ Geological survey of Cyprus, Cyprus
}

\begin{abstract}
The Pissouri basin (Cyprus Island) corresponds to a small tectonically controlled depression elongated NNW-SSE and widening southward in the direction of the deep Mediterranean domain. In the centre of the basin, the section Pissouri South, about 100 m thick, consists of well-preserved cyclic marine sediments including laminated brownish layers alternating with grey homogeneous marls. Plankton biostratigraphy (calcareous nannofossil and planktonic foraminifera) revealed a remarkable number of biovents bracketing the Zanclean-Piacenzian boundary.

In particular the Highest Occurrence (HO) of Reticulofenestra pseudoumbilicus suggests the presence of NN14/15-NN16 nannofossil biozone boundary, dated at 3.84 Ma. Additionally the defined planktonic foraminiferal MPL3-MPLAa and MPLAa-MPL4b zone boundaries point to ages between 3.81 and $3.57 \mathrm{Ma}$, in Pissouri North section. Zanclean/Piacenzian boundary (3.6 Ma) is placed at $75.8 \mathrm{~m}$ from the base of the section, considering Discoaster pentaradiatus top paracme (3.61 Ma) and Globorotalia crassaformis first influx (3.6 Ma) bioevents.

The cyclically developed sapropelic layers around the Zanclean - Piacenzian boundary suggest a climate characterized by a period of warm temperate conditions and a highly stratified water column that occurred at times of precession minima.
\end{abstract}

Key words: calcareous nannofossil, foraminifera, fossil Pissouri Basin, Zanclean-Piacenzian.

\section{Introduction}

The Neogene-Quaternary marine stratigraphy exposed on land in the Mediterranean region has been of interest to Earth scientists and has become the reference standard for the chronostratigraphy of this time interval (Berggren, 1971; Rio et al., 1984, 1991, 1997). Calcareous plankton biostratigraphy, mainly based on the appearance/disappearance and relative abundance patterns of selected species of planktonic foraminifera and calcareous nannofossils, provides high time resolution and accurate correlation at regional and global scale and is widely used for a first-order age control in many Mediterranean Neogene and Quaternary marine successions (Cita, 1973,1975; Cita \& Gartner, 1973; Rio et al., 1988, 1990; Hilgen, 1991; Sprovieri, 1992, 1993; Cita et al., 1996; Di Stefano et al., 1996; Lourens et al., 1996; Di Stefano, 1998; Raffi et al., 2006). 


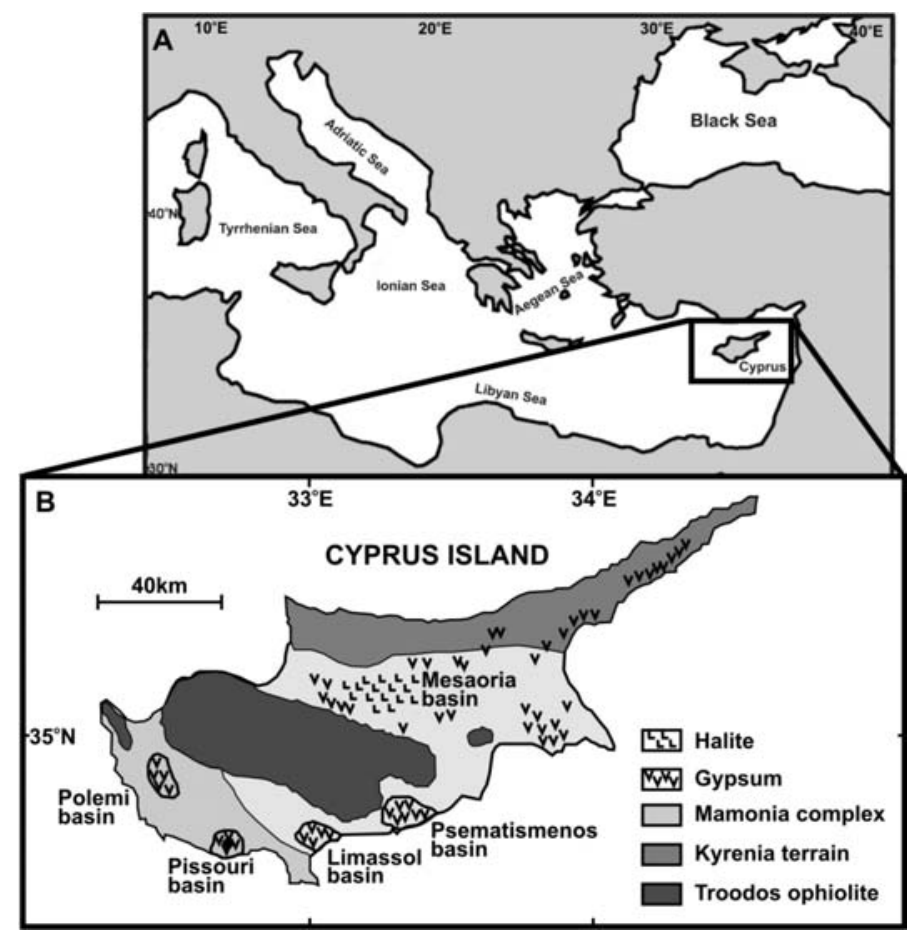

Fig. 1: a) Generalized map of the Mediterranean Sea. Cyprus is located in the eastern Mediterranean Sea. B) Simplified geological sketch map of the Cyprus Island (modified after Robertson et al., 1991; Stow et al., 1995; Krijgsman et al., 2002 and Kouwenhoven et al., 2006).

Simultaneously, the dynamics of calcareous planktonic communities are of paramount significance in palaeoenvironmental studies because they quickly respond to oceanographic changes (primary production, water stratification, temperature, salinity, etc.).

Cyprus is located in the eastern Mediterranean Sea (Fig. 1). The island is built up from three major tectonostratigraphic terrains namely Troodos, Kyrenia and Mamonia (Robertson et al., 1991). The Neogene and Quaternary marine succession of the island have been recognized in five main sedimentary sub-basins (Fig. 1). The Pissouri basin is one of these, which is located on the SW of island. It corresponds to a small tectonically controlled depression elongated NNW-SSE and widening southward in the direction of the deep Mediterranean domain. Based on data from Robertson et al. (1991), five sedimentary formations have been recognized in the basin and adjacent regions: PlioPleistocene succession represented by Nicosia and Athalassa formations, Kalavassos Formation belongs to Messinian evaporites, whereas Eocene-Miocene limestone succession is distinguished in Lefkara and Pachna formations.

The Pissouri South section, about $100 \mathrm{~m}$ in thickness, is characterised by the deposits of Pissouri marlstone unit (Stow et al., 1995) which belongs to Nicosia formation. It is located in the centre of the Pissouri sub-basin and offers the opportunity to study the assemblage composition of calcareous plankton contents (calcareous nannofossil and planktonic foraminifera). In this study, we present the results of a tighter integrated calcareous plankton biostratigraphic examination of an early Pliocene marine succession outcropping in the section and evaluate the climate variability during this interval. 


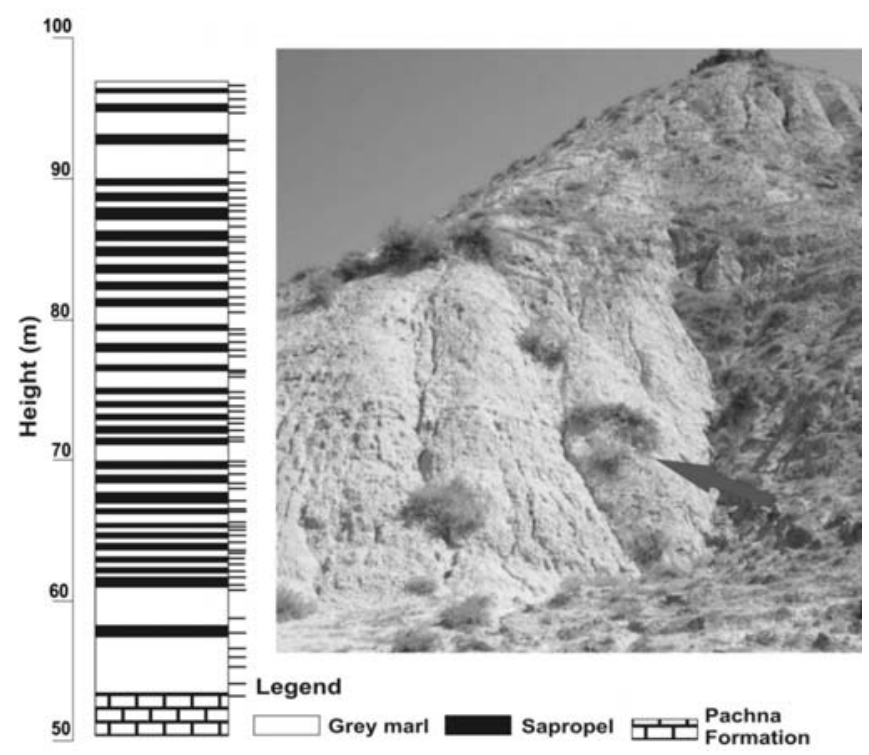

Fig. 2: Lithology and position of samples of the Pissouri South section.

\section{Materials and methods}

The studied Pissouri South section consists of well-preserved cyclic marine sediments including laminated brownish marly layers alternating with grey homogeneous marls. These sediments are overlying Pachna limestones. We focused our analyses in the part of the section between 50-100 m height, which was measured and sampled at 0.2 to $0.5 \mathrm{~m}$ intervals (Fig. 2). This high resolution sampling allowed us to perform detailed biostratigraphical studies.

Calcareous nannofossil analyses were carried out on 72 samples. Sample preparation followed standard "smear slide" techniques. Analyses were performed using a Leica DMSP polarising light microscope at 1250x magnification by counting the marker species at least 500 specimens per sample. Moreover, the frequencies of Discoaser species are established in a count of 50 discoasterids following the methods and determination of the biostratigraphic events described in Rio et al. (1990) and Raffi et al. (2006). Results were converted to relative frequencies (percentages). In order to evaluate primary production, the depth of the nutricline, and stratification in the water column we have used the ratio between Florisphaera profunda $(\mathrm{F})$ and small gephyrocapsids (sG) abundances: $\mathrm{S}$ index $=\mathrm{F} / \mathrm{F}+\mathrm{sG}$.

A quantitative study of the planktonic foraminiferal assemblages was performed on the same samples. Each sample was washed, sieved at $150 \mu \mathrm{m}$ and then dried at $60^{\circ} \mathrm{C}$. Quantitative analysis was carried out on aliquots separated from each sample by means of a microsplitter, in order to obtain at least 300 specimens. Raw data were transformed into percentages over the total abundance of planktonic foraminifera. The palaeoclimatic curve inferred from the planktonic foraminiferal assemblages was obtained by the formula $(\mathrm{w}-\mathrm{c}) /(\mathrm{w}+\mathrm{c}) \times 100$, where $\mathrm{w}$ represents the warm-water indicators and c the cold-water indicators. The ratio Neogloboquadrina sp. (dex) / Neogloboquadrina sp. (dex) + G. ruber has been used to establish a valuable stratification index.

Twenty three samples were selected from the studied succession to assess the bottom-water condi- 


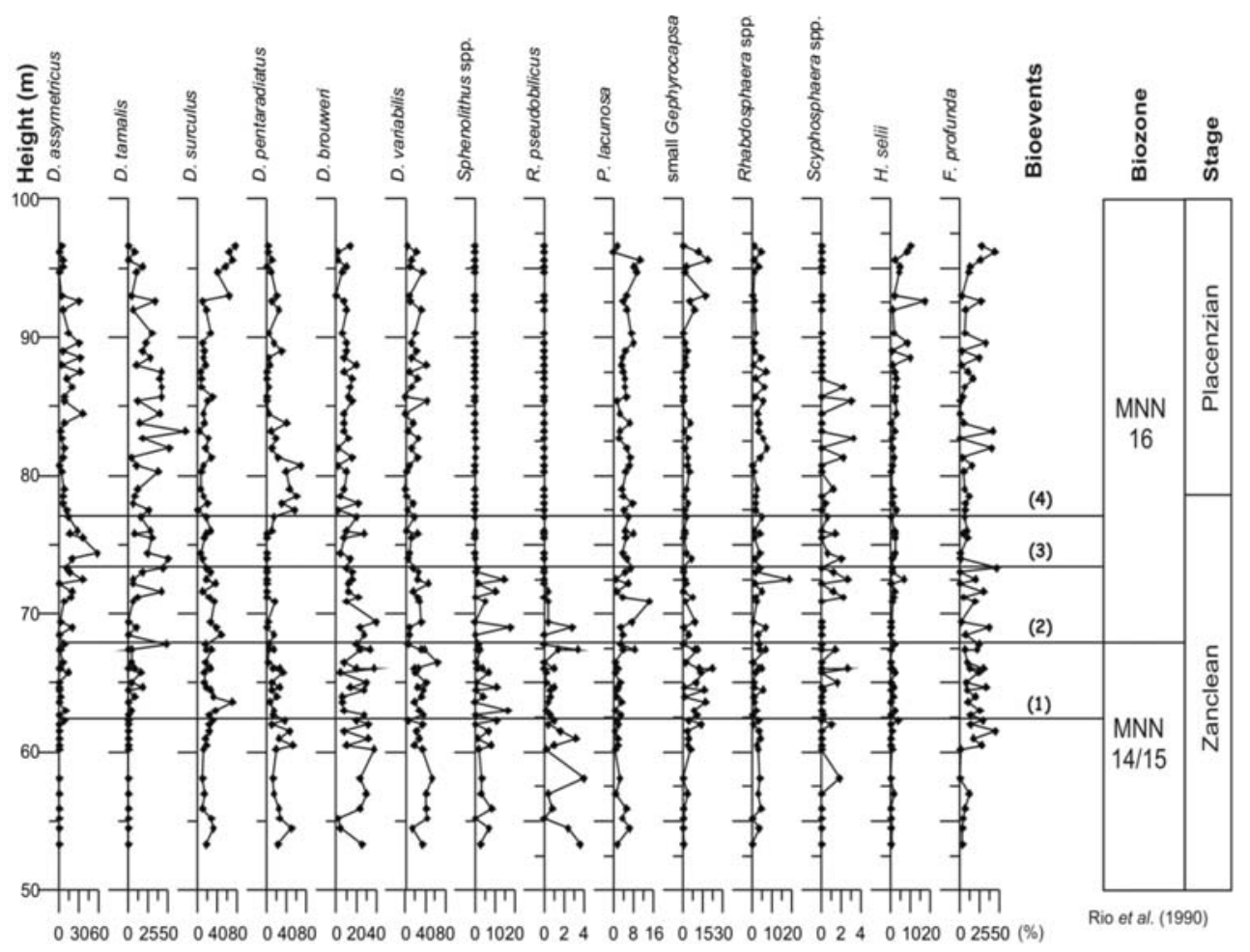

Fig. 3: Calcareous nannofossil biostratigraphy of the Pissouri south section. Quantitative distribution patterns of calcareous nannofossil marker species and the position of the main events.

tions. For the benthic quantitative analysis, the fraction larger than $150 \mu \mathrm{m}$ of the washed residue was splitted with a microsplitter to a statistically significant size, which contained more than 250 specimens of benthic foraminifera. Reconstruction of bottom water conditions concerning oxygen content was based on the presence of the dysoxic indicators in the assemblage. For this purpose, the percentage occurrence of the well established redox front dwelling taxa (Bulimina exilis, Bulimina costata, Globobulimina spp., Bolivina spathulata/dilatata) which according to Rogerson et al. (2006) is related to disturbance and/or environmental stress was calculated.

\section{Biostratigraphic results}

\subsection{Calcareous nannofossils}

Calcareous nannofossils are abundant throughout the section and generally well-preserved in all samples. Trends of representative taxa are plotted in Fig. 3.

In Pissouri South section, the nannoflora assemblage is dominated by discoasterids and sphenoliths, which provide important biostratigraphic markers in the Pliocene. Discoasters are relatively well diversified and contain Discoaster assymetricus, D. tamalis, D. surculus, D. pentaradiatus, D. brouweri and D. variabilis. Sphenolithus spp. include S. abies, S. neoabies that are the only representatives of their genus in the Pliocene. Placoliths are represented mainly by small Gephyrocapsa, followed by Reticulofenestra pseudoumbilicus (>7micron) and Pseudoemiliania lacunosa. Florisphaera profunda, 
Rhabdosphaera clavigera and Helicosphaera selli are also well represented. Scyphosphaera spp. shows an insufficient occurrence with very low proportions.

The results reveal four important calcareous nannofossil events: (1) subbottom Discoaster tamalis (2) HO (Highest Occurrence) of Reticulofenestra pseudoumbilicus, (3) HO of Sphenolithus spp., (4) top paracme Discoaster pentaradiatus. The HOs of $R$. pseudoumbilicus and Sphenolithus spp. allow us to recognize the MNN14/15-MNN16 (Rio et al., 1990) nannofossil biostratigraphic boundary dated at $3.84 \mathrm{Ma}$.

The subbottom D. tamalis is recorded at $53.0 \mathrm{~m}$, in the lower part of the section. The D. tamalis higher frequencies occur in the interval above $76.0 \mathrm{~m}$ with maximum value $(72 \%)$ at $83.2 \mathrm{~m} . R$. pseudoumbilicus presents maximum value $(3.6 \%)$ at $53.3 \mathrm{~m}$. The highest occurrence of $R$. pseudoumbilicus marks the base of MNN16 at $67.8 \mathrm{~m}$. The highest occurrence of Sphenolithus spp. occurs just above the disappearance of $R$. pseudoumbilicus, at $74.4 \mathrm{~m}$, its stratigraphic position slightly above the base of MNN16. D. pentaradiatus is marked by high abundance and a continuous distribution, except in the interval between 71.2 to $76.0 \mathrm{~m}$ being completely absent. The identification of the top of the $D$. pentaradiatus paracme at $76.0 \mathrm{~m}$ allows the recognition of the lower part of the MNN16 zone, just above the extinction level of Sphenolithus spp. The age proposed for this event is $3.61 \mathrm{Ma}$ (Lourens et al., 2004) and can be used to approximate in the Mediterranean the base of the Piacenzian Stage (3.60 Ma).

\subsection{Planktonic foraminifera}

Planktonic foraminifera are abundant throughout the section and well-preserved in all samples. The distribution pattern of the representative taxa is plotted in Fig. 4.

Planktonic foraminiferal assemblage is characterized by high abundances of G. ruber, G. obliquus, G. apertura, G. trilobus and O. universa. All these species are indicative of warm and oligotrophic conditions (Hemleben et al., 1989). Cool water species are represented by $G$. scitula, T. quinueloba, although in low percentages and G. glutinata (3-15\%). High abundances are also recorded for Neogloboquadrina sp. dextral coiled specimens and Sphaeroidinellopsis, whereas the distribution pattern of G. margaritae, G. puncticulata and G. crassaformis is used to detect the biostratigraphic framework of the section following the zonation of Cita 1973, 1975b, emended by Sprovieri, 1992.

Six planktonic foraminiferal bioevents were recognized: (1) LCO (Last Common Occurrence) of Globorotalia margaritae, (2) LO (Last Occurrence) of Globorotalia margaritae, (3) FO (First Occurrence) of Globorotalia crassaformis, (4) disappearance of Globorotalia puncticulata, (5) reappearance of $G$. crassaformis and (6) reappearance of $G$. puncticulata.

The G. margaritae zone MPL3 is clearly identified at the base of the section characterized by the high abundance of G. margaritae (up to 20\%), the occurrence of G. puncticulata (5-10\%) and Sphaeroidinellopsis (2-5\%). The LCO of G. margaritae (10\%) is recorded at $61 \mathrm{~m}$ and its LO at 69 $\mathrm{m}$ of the section. The last bioevent has been dated by Lourens et al. $(1996 ; 2004)$ at $3.81 \mathrm{Ma}$ and marks the end of MPL3 biozone and the base of MPL4a. The FO of G. crassaformis is recorded at $76 \mathrm{~m}$ and marks the Zaclean/Placentian boundary at 3.60Ma (Lourens et al., 1996). The FO of $G$. crassaformis closely approximates the temporary disappearance of G.puncticulata, at $3.57 \mathrm{Ma}$, and also the transition to MPL $4 \mathrm{~b}$ at $78 \mathrm{~m}$. Above this level and up to $87 \mathrm{~m}$ of the section, G. crassaformis is completely absent. The reappearance of this species has been dated at $3.35 \mathrm{Ma}$ and predates the reappearance of G. puncticulata at 3.31 Ma recorded at $29 \mathrm{~m}$. 


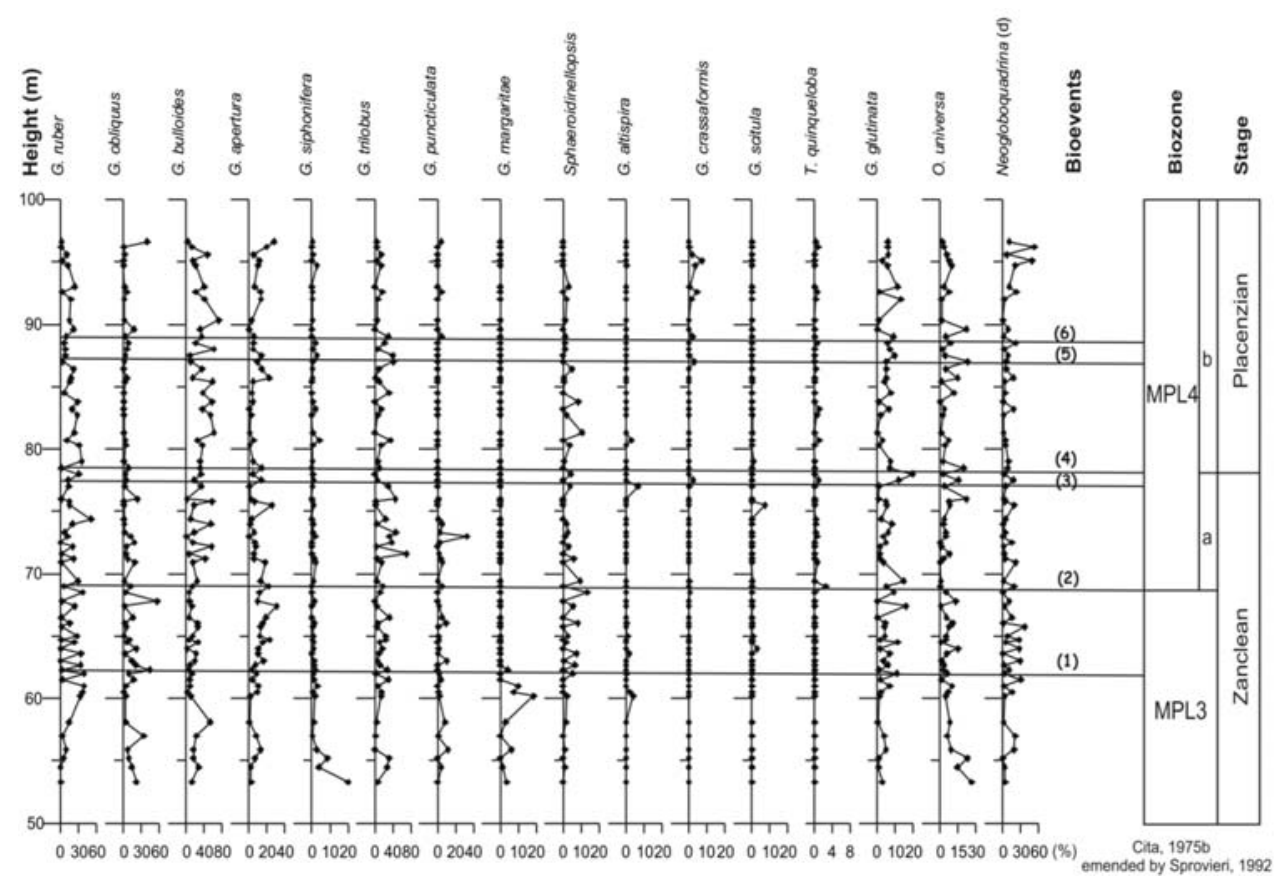

Fig. 4: Planktonic foraminiferal biostratigraphy of the Pissouri south section.

\section{Sapropelic layers at Pissouri North Section}

Micropaleontological analyses in this study also show direct relationships with lithological changes and confirm the presence of numerous cycles (Fig. 5). High relative abundant of TOC (Triantaphyllou et al., 2008) indicates that these layers can be associated with sapropelites. The marly levels of the Pissouri section can be correlated to grey and sapropelitic sediments in contemporaneous sections throughout the Mediterranean. Pliocene to Holocene Mediterranean sediments contain numerous sapropels (dark-coloured organic-rich sedimentary layers), which demonstrate that dramatically different conditions periodically occurred and coincided with changes in global and regional climate (Cita et al. 1977; Vergnaud-Grazzini et al., 1977). Detailed work in southern eastern Mediterranean sections (Jonkers, 1984; Verhallen, 1987, 1991; Hilgen, 1991) has shown that Pliocene sapropels are correlative and have a coherent and distinct cyclic pattern which correspond closely with minima in the precessional index (e.g. Rossignol-Strick, 1983; Hilgen, 1991; Lourens et al., 1992) when perihelion occurs in the Northern Hemisphere summer (Rossignol-Strick, 1983, 1985; Hilgen, 1991).

Florisphaera profunda (Fig. 5A) is a species restricted to the light-limited, lower euphotic zone (Winter et al., 1994) and has proven to be a very reliable proxy to locate the nutricline-thermocline level (Molfino \& McIntyre, 1990) being important element of sapropel layers (Castradori, 1993). In order to trace stratification and nutricline fluctuations, we used the ratio between Florisphaera profunda $(\mathrm{F})$ and small gephyrocapsids $(\mathrm{sG})$ ) abundances: $\mathrm{S}=\mathrm{F} / \mathrm{F}+\mathrm{sG}$. The increase of the nutricline proxy (Molfino \& McIntyre, 1990) F. profunda vs the high nutrient indicator (Young, 1994) gephyrocapsids suggests high values of $\mathrm{S}$ index (Fig. 5E), that imply the gradual establishment of stratified conditions and the onset of a nutrient-rich environment in the deep photic zone during sapropel 


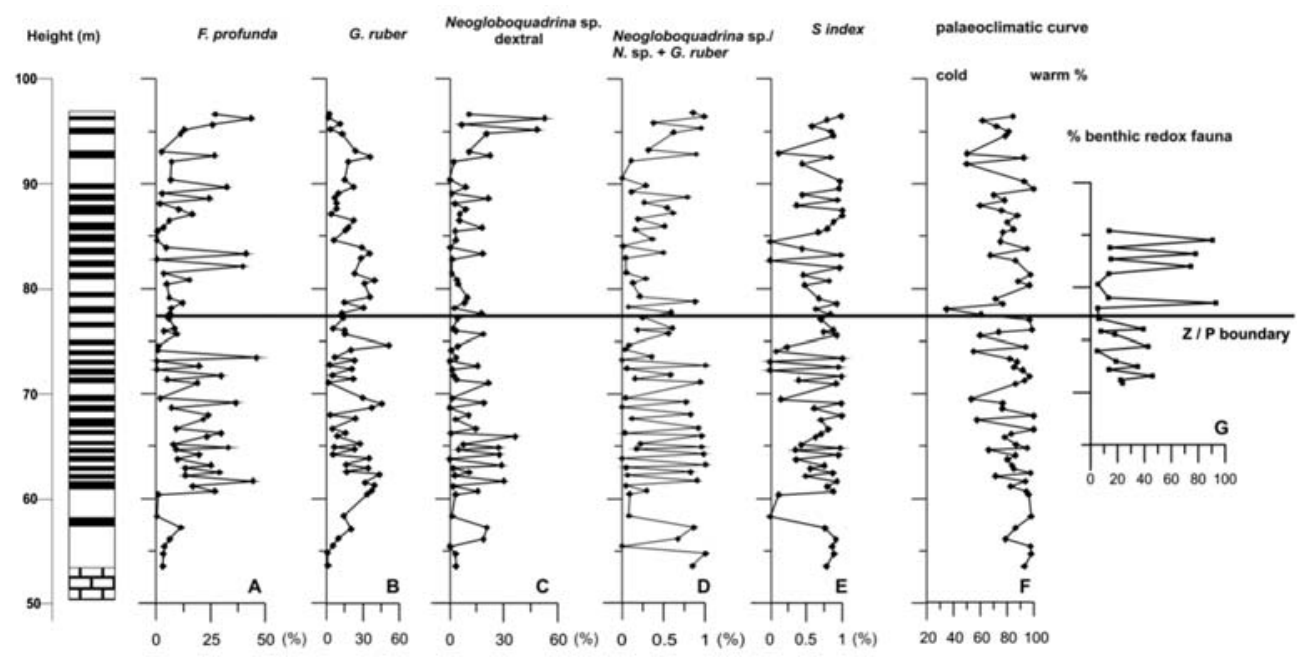

Fig. 5: Sapropelic layers at Pissouri South section.

formation. Higher abundance of Rhabdosphaera spp. at the same levels implies oligotrophic surface waters due to the increased stratification of the water column. Intervals of increased abundance of F. profunda and Rhabdosphaera spp. alternate with those of intense mixing of the surface waters that are featured by the intense presence of gephyrocapsids and anticorrelate to $F$. profunda.

The ratio Neogloboquadrina sp. (dex) / Neogloboquadrina sp. (dex) + G. ruber (Fig. 5D) has been used as additional stratification index that displays a similar trend (Fig. 5). Neogloboquadrina sp. (dex) is observed to be abundant in deep chlorophyll maxima (DCM) and, therefore, is assumed to proliferate under high productivity surface water masses and/or stratified surface water conditions. In the Mediterranean Sea, high abundance of Neogloboquadrina sp. (dex), (Fig. 5C) is often associated with sapropel layers (Rohling \& Gieskes, 1989) and high abundance of Globigerinoides ruber (Fig. 5B), indicating intensive surface water stratification during relatively warm summers and a seasonal DCM (Lourens et al., 1992).

The continuous alternations in calcareous nannofossil and planktonic foraminiferal assemblages are reflected to the pronounced lithological cyclicity presented in the Pissouri South section. The sapropelites developed close to Zanclean/Piacenzian boundary suggest a climate characterised by a period of warm temperate conditions (Fig. 5F) and a highly stratified water column that occurred at times of precession minima.

These palaeoclimatic conditions enhanced palaeoproductivity and limited the availability of dissolved oxygen in bottom waters, temporarily establishing dysoxic conditions. At the same levels, an oligotypic benthic foraminiferal assemblage prevails. The fauna is entirely composed of the wellestablished redox-front taxa with Bulimina exilis making up to $94 \%$ of the total benthic assemblage (Fig. 5G). Bulimina exilis is often associated with sapropels formed under conditions of significant oxygen depletion (Jonkers 1984). Therefore, the high frequency values of this species may indicate a temporal reaction of benthic foraminifera to the input of fresh water organic matter. Hence, the shallowing of the redox front could be linked to the increase of food availability that leads to an increased consumption of oxygen (Jorissen et al., 1995). 


\section{Conclusions}

Calcareous plankton biostratigraphy in this study confirm the presence of Zanclean/Piacenzian boundary of the early Pliocene marine succession in the Pissouri South section. Z/P boundary (3.6 $\mathrm{Ma}$ ) is placed at $75.8 \mathrm{~m}$ from the base of the section, considering Discoaster pentaradiatus top paracme (3.61 Ma) and Globorotalia crassaformis first influx (3.6 Ma) bioevents.

Micropaleontological analysis revealed the presence of numerous cycles that resulted in the sapropelitic/homogeneous marl alternations. The sapropelites developed around the Zanclean - Piacenzian boundary suggest a climate characterised by fluctuations of warm - temperate to humid subtropical conditions associated with a highly stratified water column at times of precession minima.

\section{Acknowledgements}

Funding has been provided by Research Projects 70/3/7093 and 70/4/3570 financed by Cyprus Geological Survey and NKUA-SARG.

\section{References}

Berggren, W.A., 1971. Tertiary boundaries and correlations. In Funnell, B.M. and W.R. Riedel, (eds). The Micropaleontology of Oceans. Cambridge Univ. Press, pp. 693-809.

Castradori, D., 1993. Calcareous nannofossil and the origin of Eastern Mediterranean sapropels. Paleoceanography, 8, 459-471.

Cita. M.B., 1975. Studi sul Pliocene e sugli strati di passaggio da1 Miocene al Pliocene VIII. Planktonic foraminiferal biozonation of the Mediterranean Pliocene deep sea record. revision. Rivista Italiana di Paleontologia, 81 (4), 527-544.

Cita, M.B., and Gartner, S., 1973. Studi sul Pliocene e sugli strati al passaggio dal Miocene al Pliocene. IV. The stratotype Zanclean foraminiferal and nannofossil biostratigraphy. Rivista Italiana di Paleontologia e Stratigrafia, 79, 503-558.

Cita, M.B., Rio, D., Hilgen, F., Castradori, D., Lourens, L., and Vergerio, P.P., 1996. Proposal of the Global Boundary Stratotype Section and Point (GSSP) of the Piacenzian Stage (middle Pliocene. Inter. Comm. on Stratigr, Subcomm. on Neogene Stratigraphy.

Cita, M.B., Vergnaud-Grazzini, C., Robert, C., Charnley. H., Ciaranh, N., D’ Onofrio, S., 1977. Paleoclimatic record of a long deep sea core from the eastern Mediterranean. Quaternary Research, 8, 205-235.

Cita, M.B., 1973. Pliocene biostratigraphy and chronostratigraphy. In W.B.F. Ryan, K.J. Hsii et al. (eds), Initial Reports of the Deep Sea Drilling Project, v. 13. U.S. Government Printing Office, Washington, pp. 1343-1379.

Di Stefano, E., 1998. Calcareous nannofossil quantitative biostratigraphyof Holes 969E and 963B (Eastern Mediterranean). In Robertson, A.H.F., Emeis, K.-C., Richter, C., and A. Camerlenghi, (eds), Proceedings of the Ocean Drilling Program, Scientific Results, 160, 99-112.

Di Stefano, E., Sprovieri, R., Scarantino, S., 1996. Chronology of biostratigraphic events at the base of the Pliocene. Palaeopelagos, 6, 401-414.

Hilgen, F.J., 1991. Extension of the astronomically calibrated (polarity) time scale to the Miocene/Pliocene boundary. Earth and Planetary Science Letters, 107, 349-368.

Jonkers, H.A., 1984. Pliocene benthonic foraminifera from homogeneous and laminated marls on Crete. Utrecht Micropaleontological Bulletin, 31, 179 pp.

Jorissen, F.J., De Stigter, H.C., Vidmark, J.V. 1995. A conceptual model explaining benthic foraminiferal microhabitats, Marine Micropalaeontology 37, 67-76. 
Kouwenhoven, T.J., Morigi, C., Negri, A., Giunta, S., Krijgsman, W., Rouchy, J.-M., 2006. Paleoenvironmental evolution of the eastern Mediterranean during the Messinian: constraints from integrated microfossil data of the Pissouri Basin (Cyprus). Marine Micropaleontology, 60 (1), 17-44.

Krijgsman, W., Blanc-Valleron, M.-M., Flecker, R., Hilgen, F.J., Kouwenhoven, T.J., Merle, D., OrszagSperber, F., Rouchy, J.M., 2002. The onset of the Messinian salinity crisis in the eastern Mediterranean (Pissouri Basin, Cyprus). Earth and Planetary Science Letters, 194, 299-310.

Lourens, L.J., Antonarakou, A., Hilgen, F.J., Van Hoof, A.A.M., Vergnaud-Grazzini, C., Zachariasse, W.J., 1996. Evaluation of the Plio-Pleistocene astronomical timescale. Paleoceanography, $11(4), 391-413$.

Lourens, L.J., Hilgen, F.J., Gudjonsson, J., Zachariasse, W.J., 1992. Late Pliocene to Early Pleistocene astronomically-forced sea surface productivity and temperate variations in the Mediterranean. Marine Micropaleontology, 19, 49-78.

Lourens, L., Hilgen, F., Shackleton, N. J., Laskar, J., Wilson, J., 2004. The Neogene period. In F. M. Gradstein et al. (eds), A Geologic Time Scale 2004, p. 409-440, Cambridge University Press.

Molfino, B., McIntyre, A., 1990. Precessional forcing of nutricline dynamics in the Equatorial Atlantic. Science, 249, 766-769.

Raffi, I., Backman, J., Fornaciari, E., Palike, H., Rio, D., Lourens, L., Hilgen, F., 2006. A review of calcareous nannofossil astrobiochronology encompassing the past 25 million years. Quaternary Science Reviews, 25, 3113-3137.

Rio, D., Raffi, I., Villa, G., 1990. Pliocene-Pleistocene calcareous nannofossil distribution patterns in the western Mediterranean. In Kastens, K.A., Mascle, J., et al. (eds), Proc Sci Results ODP, 107, p. 513532, ODP College Station, TX.

Rio. D., Sprovieri, R. Ram, I., 1984. Calcareous plankton biostratigraphy and biochronology of the Plioceneelower Pleistocene succession of the Capo Rossello area. Sicily. Marine Micropaleontology, 9, 135-180.

Rio, D., Sprovieri, R., Raffi, I., Valleri, G., 1988. Biostratigrafia e paleoecologia della sezione stratotipica del Piacenziano. Bollettino della Societa Paleontologica Italiana, 27, 213-238.

Rio. D., Sprovieri. R. Thunell, R.C., 1991. Pliocene-Lower Pleistocene Chronostrdtigraphy: A re-evaluation of Mediterranean-type sections. Bulletin of the Geological Society of America, 103, 1049 - 1058.

Rio, D., Channell, J.E.T., Bertoldi, R., Poli, M.S.,Vegerio, P.P., Raffi, I., Sprovieri, R., Thunell, R.C., 1997. Pliocene sapropels in the northern Adriatic area: Chronology and palaeoenvironmental significance: Palaeogeography, Palaeoclimatology, Palaeoecology, 135, 1-25.

Robertson, A.H.F., Eaton, S., Follows, E.J. and McCallum, J.E., 1991. The role of tectonics versus global sea-level change in the Neogene evolution of the Cyprus active margin. International Association of Sedimentologists Special Publication, 12, 331-369.

Rohling, E.J., Gieskes, W.W.C., 1989. Late Quaternary changes in Mediterranean intermediate water density and formation rate. Paleoceanography, 4, 531-545.

Rogerson, M., Kouwenhoven, T.J., Van der Zwaan, G.J., O’ Neill, B.J., Postma, G., Kleverlaan, K., Tijbosch, H. 2006. Benthic foraminifera of a Miocene canyon and fan, Marine Micropalaeontology 60, 295-318.

Rossignol-Strick, M., 1983. African monsoons, an immediate climate response to orbital insolation. Nature, 304, 46-49.

Rossignol-Strick. M., 1985. Mediterranean Quaternary sapropels. an immediate response of the African monsoon to variation of insolation. Palaeogeography, Palaeoclimatology, Palaeoecology, 49, 237-263.

Sprovieri, R., 1993. Pliocene Early Pleistocene astronomically forced planktonic foraminifera abundance 
fluctuations and chronology of Mediterranean calcareous plankton bioevents. Rivista Italiana di Paleontologia e Stratigrafia, 99 (3), 371-414.

Stow, D.A.V., Braakenburg, N.E., Xenophontos, C., 1995. The Pissouri Basin fan-delta complex, southwestern Cyprus. Sedimentary Geology, 98, 254-262.

Triantaphyllou, M., Antonarakou, A., Lourens, L., Ziveri, P., Tsolakis, E., Tsaila-Monopolis, S., Theodorou, G., Dermitzakis, M., Kontakiotis, G., Konstantinidou, E., Athanasiou, M., 2008. Calcareous plankton events and climate variability during late Zanclean in the eastern mediterranean (Pissouri basin, Cyprus). $33^{\text {th }}$ International Geological Conference (IGC), Oslo, Norway.

Vergnaud-Grazzini, C., Ryan, W.B.F., Cita, M.B., 1977. Stable isotopic fractionation, climate change and episodic stagnation in the Eastern Mediterranean during the Late Quaternary. Marine Micropaleontology, 2, 353-370.

Verhallen, P.J.J.M., 1987. Early development of Bulimina nearginuta in relation to paleoenvironmental changes in the Mediterranean Pliocene. Kon. Ned. Akad. Wet., Ser. B 90, 161-180.

Verhallen, P.J.J.M., 1991. Late Pliocene to Early Pleistocene Mediterranean mud-dwelling foraminifera; influence of a changing environment on community structure and evolution. Utrecht Micropaleontological Bulletin, 40, $187 \mathrm{pp}$.

Winter, A., Jordan, R. W., Roth P., 1994. Biogeography of living Coccolithophores in oceanic waters. In Winter A. and W.G. Siesser (eds), Coccolithophores, p. 13-27, Cambridge University Press.

Young, J.R., 1994. Functions of coccoliths. In Winter A. and W.G. Siesser (eds), Coccolithophores, p. 1327, Cambridge University Press. 